\title{
Selection of bacteria and fungi for control of soilborne seedling diseases of maize
}

\author{
Tobias Pfeiffer ${ }^{1} \cdot$ Astrid von Galen ${ }^{1} \cdot$ Petra Zink ${ }^{1} \cdot$ Sebastian Hübner ${ }^{1} \cdot$ Ada Linkies $^{1} \cdot$ Dieter Felgentreu $^{2}$. \\ Jannika Drechsel ${ }^{3} \cdot$ Tim Birr $^{3}$ - Olaf Röder ${ }^{4} \cdot$ Mathias Kotte $^{4} \cdot$ Kristin Dietel $^{5} \cdot$ Helmut Junge $^{5}$ - Elisa Schwarz ${ }^{5}$. \\ Eckhard Koch ${ }^{1}$
}

Received: 18 November 2020 / Accepted: 5 July 2021 / Published online: 3 August 2021

(c) The Author(s) 2021

\begin{abstract}
Plant-based screening experiments were conducted with the aim of identifying biocontrol bacteria and fungi for seed treatment of maize. Candidate microorganisms were evaluated for their protective effects against soilborne infections by species of Fusarium, Globisporangium (syn. Pythium) and Rhizoctonia. The microorganisms tested were bacteria and fungi from maize roots or other sources, including some active microbial components of commercial biocontrol products. Due to the method of isolation chosen, the majority of bacteria from maize roots were spore formers, most of them species of the genera Bacillus, Brevibacillus and Paenibacillus. In pot tests with the potting substrate inoculated with F. culmorum, the level of control provided by seed treatment with the most efficacious bacterial and fungal isolates was comparable or close to the chemical reference seed treatment thiram. The most effective bacteria were species of Pseudomonas, Burkholderia and Streptomyces. Among a subset of approx. 100 bacteria studied, the in vivo and in vitro activities against $F$. culmorum were only weakly correlated, although some strains deviated from this pattern. The most effective fungi were two strains of Clonostachys rosea and isolates of Trichoderma. The latter and a strain of Gliocladium virens provided also protection against $R$. solani. Activity against Globisporangium ultimum was recorded for one isolate of Trichoderma and the two strains of $C$. rosea. A reduction in the impact of seedborne F. culmorum was also observed after seed treatment with two strains of F. oxysporum f. sp. strigae. The results are discussed in relation to previous reports on rhizosphere bacteria of maize and their use in biocontrol of plant pathogens or for plant growth promotion.
\end{abstract}

Keywords Maize $\cdot$ Biocontrol $\cdot$ Seed treatment $\cdot$ Soilborne pathogens

Eckhard Koch

Eckhard.Koch@Julius-Kuehn.De

1 Federal Research Centre for Cultivated Plants, Institute for Biological Control, Julius Kühn Institute, Heinrichstr. 243, 64287 Darmstadt, Germany

2 Federal Research Centre for Cultivated Plants, Institute for Ecological Chemistry, Plant Analysis and Stored Product Protection, Julius Kühn Institute, Königin-Luise-Straße 19, 14195 Berlin, Germany

3 Department of Plant Diseases and Crop Protection, Institute of Phytopathology, Faculty of Agricultural and Nutritional Science, Christian-Albrechts-University of Kiel, Hermann-Rodewald-Straße 9, 24118 Kiel, Germany

4 EVONTA-Service GmbH, Bautzner Landstraße 45, 01454 Radeberg, Germany

5 ABiTEP GmbH, Glienicker Weg 185, 12489 Berlin, Germany

\section{Introduction}

In maize, seedling emergence and establishment of vigorous stands can be impeded by a variety of seed- and soilborne fungal pathogens that attack seeds and seedlings. Fungi of the genus Fusarium are among the most important seedand soilborne pathogens of maize, causing seed rot, root rot and seedling blight. The fungi $F$. verticillioides, $F$. proliferatum, $F$. subglutinans, $F$. oxysporum, $F$. temperatum and $F$. graminearum are especially involved in maize seedling diseases (Munkvold and O'Mara 2002; Pintos Varela et al. 2013). In addition to Fusarium spp., Rhizoctonia solani and different species of Globisporangium (syn. Pythium) are important soilborne pathogens of maize (Buddemeyer et al. 2004; Thomsen et al. 2018; Schmidt et al. 2020). Maize seed is typically treated with chemical fungicides in order to reduce the impact of these pathogens (Sharma et al. 2015). 
Physical seed treatments like hot water (Rahman et al. 2008) or aerated steam (Forsberg et al. 2005) are rarely used on maize. In the food sector, different nonthermal physical methods like pulsed electric fields (Evrendilek et al. 2019), cold plasma (Randeniya and de Groot 2015) and electron beam irradiation (Nemţanu et al. 2014) are regarded as novel technologies for the removal of superficial microbial contaminations from seeds. Among these methods, electron beam treatment is the only that has found practical application also for the treatment of agricultural and horticultural seeds. It is based on the use of low-energy electrons and mainly effective against pathogens on the seed surface, like the spores of common bunt (Tilletia caries) or rye stripe smut (Urocystis occulta) (Cutrubinis et al. 2005; Jahn et al. 2005; Röder et al. 2009) and has also shown potential for control of Fusarium spp. on maize kernels (Peters et al. 2010).

Because physical treatments can only control pathogens on or in seeds, it appears logical to combine them with the application of microorganisms that provide protection against attack by pathogens from the soil. A large body of literature exists on the treatment of maize kernels with beneficial microorganisms. Generally, these publications describe the application of microbes to seed with the aim to enhance seedling establishment through control of pathogens (e.g. Chang and Kommedahl 1968, Vakili 1992, Mao et al. 1998) or report on seed treatments with microbes targeting mycotoxin-producing species of fusaria that colonize maize roots, stalks, ears and cobs (Pereira et al. 2011; Alberts et al. 2016).

The choice of screening methods and steps to identify microorganisms with antagonistic or growth-promoting properties have been discussed by several authors (e.g. Whipps 1987; Knudsen et al. 1997; Köhl et al. 2011; Adeniji and Babalola 2018). The papers commonly include considerations on the usefulness of in vitro methods that select for characteristics assumed to be responsible for, or contributing to, the performance of candidate antagonists on the plant. Apart from production of enzymes, phytohormones or other specific compounds like siderophores, the most discussed trait in this respect is probably the in vitro production of antifungal or antibacterial compounds. Most authors currently agree that tests based on whole plants should be the first step for screening of biocontrol agents because they are the closest to natural conditions (Daayf et al. 2003; Barnett et al. 2017). Many studies aim to identify new biocontrol agents solely from the view of the scientist wishing to obtain strains with high efficacy. However, if the final aim of the work is commercialization, factors like toxicological profiles, feasibility of cost-effective fermentation and formulation or extended shelf life are equally important and make screenings of microorganisms for commercial use in biocontrol an even more complex process (Köhl et al. 2011).
The objective of the present study was to identify microorganisms with activity against soilborne pathogens and potentially suited for the combination with the physical method of electron seed treatment. In consideration of the above, we decided to conduct a plant-based screening in pots, with the potting substrate artificially inoculated with F. culmorum (experiments with bacteria and fungi) or with G. ultimum or R. solani, respectively (experiments with fungi), using previously (Koch et al. 2020) described methodology. In most of the isolations of bacteria, we included a heating step of the root washing fluid aimed at preferentially isolating spore formers (Shafi et al. 2017). The fungi tested were comprised of isolates from maize seeds and shoots. In addition, active microbial ingredients of commercial biocontrol products were included that served both as reference and potential candidates. We also tested two strains of $F$. oxysporum f. sp. strigae developed as bioherbicides for control of Striga hermonthica on maize (Nzioki et al. 2016) for potential to reduce the impact of soilborne $F$. culmorum when applied as seed treatment. The dimethyldithiocarbamate compound thiram (TMTD) (Sharma et al. 2003) was included in all experiments with plants as the standard chemical seed treatment, fludioxonil + metalaxyl-M, was included in the experiments with G. ultimum.

\section{Materials and methods}

\section{Maize seeds}

The experiments were performed with the commercial hybrid maize seed varieties Emmy (Limagrain Europe SA, Saint-Beauzire, France), Movanna and Likeit (both from Deutsche Saatveredelung AG, Lippstadt, Germany). In the following, these seeds are termed seed lot 1 , seed lot 2 and seed lot 3, respectively. Unless stated otherwise, the seeds used had been treated with low-energy electrons by Evonta Service GmbH (Radeberg, Germany) using the company's proprietary seed treatment technology "e-ventus" (Röder et al. 2009). In pretests, germination and plant development of the electron-treated seeds were in no way impaired, indicating that they were free of pathogens or any other damage.

\section{Bacteria}

In total, 230 bacterial strains were used in this study, of which 13 were supplied by Abitep GmbH, 28 were taken from the culture collection of the Julius Kühn Institute, Institute for Biological Control, and 189 were freshly isolated from roots of maize from agricultural fields in Lower Saxony, Hesse and Schleswig-Holstein, or from roots of young maize plants raised in the growth room. In case of the latter, maize kernels not pre-treated with electrons were 
surface disinfected by submerging them in $1 \% \mathrm{NaOCl}$ in 50-ml Erlenmeyer flasks and placing the flasks for $10 \mathrm{~min}$ on a rotary shaker (220 rpm, room temperature). Thereafter, the kernels were washed in sterile distilled water and sown in pots filled with samples of soil from different habitats (agricultural fields, gardens, forest) within a $25 \mathrm{~km}$ radius around Darmstadt. The pots were then placed in a plant growth room set at 15 or $20{ }^{\circ} \mathrm{C}$ (see "Pot tests" below). Alternatively, the pots were incubated during the germination phase of the maize kernels for $2-3$ weeks at $10^{\circ} \mathrm{C}$ in the dark before they were transferred to the $20^{\circ} \mathrm{C}$ growth room.

For isolation of bacteria, the roots of the maize seedlings were carefully shaken to remove adhering soil particles and approximately $4 \mathrm{~g}$ of root mass were cut into small pieces and incubated for $30 \mathrm{~min}$ in $40 \mathrm{ml} 0.0125 \%$ Tween 80 in an ultrasonic bath. The suspensions were then diluted $1: 10,000$ and plated on $1 / 10$ strength tryptic soy agar (0.1 TSA, Merck). In most of the isolations, the suspensions were incubated for $10 \mathrm{~min}$ at $80^{\circ} \mathrm{C}$ before they were plated. After 24-72 $\mathrm{h}$ incubation at $25^{\circ} \mathrm{C}$ individual colonies differing in morphology and colour were picked and purified by multiple transfers to fresh plates. For long-term storage, the bacteria were kept at $-80{ }^{\circ} \mathrm{C}$ using the Microbank ${ }^{\mathrm{TM}}$ cryopreservation system (Pro-lab Diagnostics, Richmond Hill, Canada). Bacterial and fungal strains isolated from maize roots were given four-digit numbers in accordance with the numbering system of the culture collection of the institute.

\section{Identification of bacteria}

Isolates of interest were identified by gas chromatography analysis of whole-cell fatty acid methyl esters (FAMEs) using the Microbial Identification System (MIS) (MIDI, Inc., Newark, Delaware, USA). Preparation and analysis of FAMEs were performed according to the method described in the manufacturer's manual (Sherlock ${ }^{\circledR}$ MIS version 6.2, Technical Note 101, M. Sasser 2001). FAMEs were separated by gas chromatography (Agilent Technologies 7890A, Santa Clara, CA, USA) using a fused-silica capillary column [HP-Ultra $2(0.33 \mu \mathrm{m}, 25 \mathrm{~m}$ length $\times 0.2 \mathrm{~mm}$ diameter $)$ ]. FAME profiles of the bacterial strains were identified by comparing the results to the commercial databases (TSBA 41) with the MIS software package. The similarity index (SI\%) expresses how closely the fatty acid composition of the unknown sample compares with the mean fatty acid composition of the strain used to create the library entry listed as its match. Strains with similarity of $50 \%$ or higher and with a separation of $10 \%$ between first and second choices are considered as good matches.

In the case of three isolates, only insufficient results were obtained with MIS. Two of these were identified molecularly by PCR amplification of the $16 \mathrm{~s}$ rDNA with primers $27 \mathrm{f}$ and 1525r (Lane 1991), followed by sequencing of the
PCR products and comparison of the results with the NCBI data bank. One isolate was identified by MALDI biotyping (Bruker, Bremen, Germany) using the manufacturer's instructions (Sauer et al. 2008). The biotyping results were interpreted according to a log score scheme with a value higher than 2.0 for likely species identification.

\section{Isolation and identification of fungi}

For the isolation of fungi from maize roots, maize kernels not pre-treated with electrons were disinfected by placement for $10 \mathrm{~min}$ in $1 \% \mathrm{NaOCl}$ as described above and sown in a 60:40 (w/w) mixture of a horticultural substrate (Fruhstorfer Erde Typ P, Hawita Gruppe GmbH, Vechta, Germany) and sand. After placement of the pots in the growth room (see "Pot tests" below) for 10 days, the seedlings were uprooted, and the roots were washed under tap water to remove adhering soil particles. Pieces of root (approx. $1 \mathrm{~cm}$ ) were surface disinfected by immersion for $10 \mathrm{~min}$ in $\mathrm{NaOCl}(1 \%)$, washed in sterile distilled water and placed on potato dextrose agar (PDA, Sigma-Aldrich) supplemented with $50 \mathrm{ppm}$ streptomycin and $20 \mathrm{ppm}$ rifampicin (Sigma-Aldrich) (PDA + A). Alternatively, pieces of tissue (approx. $0.5 \mathrm{~cm}$ ) cut aseptically from the second or third stem nodes were placed on the plates above. The nodes were taken from 10-week-old maize plants raised in the greenhouse in the potting mix (non-heat treated) described above.

After incubation at $20^{\circ} \mathrm{C}$ for 5 days, single hyphae growing from the tissue were transferred to fresh plates and single spore isolates were prepared. Altogether, three isolates from roots and three from nodes were established on PDA and identified based on morphology and partial sequencing of the nuclear rDNA after PCR amplification of the ITS1 and ITS4 region as previously described (Koch et al. 2020). Trichoderma atroviride strain SC1, Gliocladium virens GL-21 and Clonostachys rosea strain J1446 (Gliocladium catenulatum strain J1446) were isolated from the commercial products Vintec (Belchim, Londerzeel, Belgium), SoilGard (Certis, Columbia, MD, USA) and Prestop (Verdera Oy, Espoo, Finland), respectively. Small quantities of the products were suspended in sterile distilled water, and the suspensions were diluted and plated on PDA + A. From outgrowing mycelia, cultures were established on PDA, and single spore isolates were prepared. Clonostachys rosea strain IK726 (Jensen et al. 2007) was taken from the culture collection of the institute. Fusarium oxysporum f. sp. strigae strains $5 \mathrm{a}$ and $6 \mathrm{a}$ were provided by the toothpick project (Nzioki et al. 2016) and maintained on PDA.

\section{Seed inoculation with bacteria and fungi}

The streptomycete isolates were cultured for 14 days at $25{ }^{\circ} \mathrm{C}$ on Petri plates on GYM medium (4 g glucose, $4 \mathrm{~g}$ 
yeast extract, $10 \mathrm{~g}$ malt extract, $2 \mathrm{~g} \mathrm{CaCO}_{3}, 16 \mathrm{~g}$ agar per litre). To sporulating plates, $5-\mathrm{ml}$ sterile saline $(0.9 \% \mathrm{NaCl})$ was added and agitated with a spatula. In order to obtain sufficient quantities for seed treatment, suspensions from several plates were combined. All other bacteria were grown in shake cultures in 300-ml Erlenmeyer flasks filled with 50-ml tryptic soy broth (TSB, Merck). The medium was inoculated with bacteria from TSA plates, and the flasks were placed on a rotary shaker for $48 \mathrm{~h}(175 \mathrm{rpm})$ at $27^{\circ} \mathrm{C}$. The cultures were then diluted 1:10 with TSB, and the resulting suspensions used for seed inoculation. Bacterial concentrations were not regularly assessed. Occasional checks showed densities of $5 \times 10^{6}-1 \times 10^{8} \mathrm{CFU} / \mathrm{kernel}$. Cultures with visibly poor bacterial growth were in no case employed in the tests.

Conidial suspensions of the tested isolates of Trichoderma and Clonostachys were prepared from sporulating cultures on PDA as explained above for streptomycetes. Treatment of maize kernels with conidial suspensions of $F$. oxysporum f. sp. strigae strains $5 \mathrm{a}$ and $6 \mathrm{a}$ was performed as described previously for different fusaria (Koch et al. 2020). In the first experiment, the spore concentrations in the inoculum suspensions were $1 \times 10^{7}$ and $1 \times 10^{8}$ conidia per $\mathrm{ml}$ for strain $5 \mathrm{a}$ and $2 \times 10^{6}$ and $2 \times 10^{7}$ for the poorer sporulating strain $6 \mathrm{a}$. In the second experiment, the spore suspensions of both strains were adjusted to $1 \times 10^{6}$ and $1 \times 10^{7}$.

Seed inoculation was performed by placement of maize kernels for $10 \mathrm{~min}$ in the bacterial or fungal suspensions. The kernels were then separated from the liquid by passing through a sieve, dried overnight in a laminar flow hood and sown the following day. As chemical reference, Thiram SC 700 (686 g / thiram) and Maxim XL (25 g/l fludioxonil $+10 \mathrm{~g} / \mathrm{l}$ metalaxyl-M) were used. Forty $\mathrm{g}$ of maize seeds was filled in a flask, and $450 \mu \mathrm{l}$ of a 1:10 dilution of Maxim XL were added. In the case of thiram, $900 \mu 1$ of a mix containing an organic binder, water and Thiram SC700 w ere applied at a rate corresponding to $4 \mathrm{~g}$ active ingredient per $\mathrm{kg}$ of seed. After vigorously shaking for at least two minutes, the flasks were emptied out and the seeds allowed to dry.

\section{Preparation of inoculum for mixing into potting substrate}

For all experiments involving inoculation of the potting substrate, the pathogenic fusaria ( $F$. culmorum, $F$. verticillioides, $F$. subglutinans, $F$. proliferatum) as well as $F$. oxysporum f. sp. strigae were grown on millet seeds (Koch et al. 2020). Briefly, to $100 \mathrm{~g}$ autoclaved millet seeds in 1-1 Erlenmeyer flasks, $30-\mathrm{ml}$ conidial suspension $\left(1.5 \times 10^{4}\right.$ conidia per $\mathrm{ml}$ ) of the respective fusaria were added. The flasks were incubated at $20{ }^{\circ} \mathrm{C}$ in darkness for $72 \mathrm{~h}$ and agitated once a day to prevent the formation of clots.

G. ultimum (CC-3) and R. solani AG2-2 IIIB were cultivated on seeds of buckwheat (Schmidt et al. 2020) and pearl barley, respectively. The substrates were filled into 1-1 Erlenmeyer flasks at $100 \mathrm{~g}$ per flask. After autoclaving, ten agar discs (10 mm diameter) from actively growing cultures of the pathogens on PDA and 50-ml (R. solani: $30 \mathrm{ml}$ ) sterile distilled water were added to each flask. The flasks were incubated at $20^{\circ} \mathrm{C}$ in darkness for $96 \mathrm{~h}(R$. solani: $72 \mathrm{~h})$ and agitated once a day.

\section{Pot tests}

The experiments with potting substrate inoculated with $F$. culmorum, R. solani or G. ultimum were performed in $10 \times 10 \mathrm{~cm}$ plastic pots in a pre-heated $\left(48 \mathrm{~h}\right.$ at $\left.60^{\circ} \mathrm{C}\right) \mathrm{mix}$ of a horticultural substrate and sand (see "Isolation and identification of fungi" above) adjusted to a gravimetric water content of 0.45 . The pathogen inoculum, prepared as described in the previous paragraph, was evenly mixed into the potting substrate at concentrations of $0.5 \%$ (F. culmorum), $0.1 \%$ (R. solani) or $1.5 \%$ (G. ultimum), respectively. After sowing, the pots were covered with a layer (approx. $1-\mathrm{cm}$ thick) of vermiculite, and their weight was recorded. They were then placed in a randomized design in a plant growth room at $20{ }^{\circ} \mathrm{C}$ and $50-70 \%$ relative humidity under $16 \mathrm{~h}$ of light from fluorescent lamps (photosynthetically active radiation $115 \mu \mathrm{mol} / \mathrm{m}^{2} \mathrm{~s}$ ). Pots were watered individually every second day by re-adjusting their weight to the original weight $+10 \mathrm{~g}$. Two weeks after planting, the number of plants per pot was recorded, plants were cut at the crown, and the plant dry weight in each pot was determined after incubation for $48 \mathrm{~h}$ at $60^{\circ} \mathrm{C}$. Details of experimental design (number of seeds per pot, number of pots per experiment, number of experiments) are stated in the "Results" section in the legends of the respective figures.

\section{Dual cultures}

Of the 230 bacterial isolates used in this study, a subset of 107 were employed in dual-culture assays with the pathogens Fusarium culmorum VIII18 (Koch et al. 2020), $R$. solani AG2-2 IIIB and G. ultimum (CC-3). The tests were run with three plates per bacterial isolate - pathogen combination. The bacteria were applied on PDA in Petri plates $(10 \mathrm{~cm}$ diameter) in two parallel streaks at a distance of $5 \mathrm{~cm}$. After two days of incubation at $25^{\circ} \mathrm{C}$, mycelial plugs ( $8 \mathrm{~mm}$ diameter) from freshly grown cultures of the pathogens on PDA were placed in the centre of the plates. The controls consisted of plates not carrying bacterial streaks. The dual cultures were then incubated at $25{ }^{\circ} \mathrm{C}$ until the fungal colonies of the controls reached the edge of the plates, which was after 2 days for G. ultimum, 5 days for $R$. solani and 5-6 days for F. culmorum. Mycelial diameters on plates carrying bacterial streaks and on control plates were measured and used to calculate the percentage of inhibition. 
Depending on the degree of inhibition, the cultures were generally more or less oval. Measurements were taken across the narrow (shortest) diameter of the cultures and related to the diameter of the (generally circular) controls.

\section{Statistical analysis}

Data on efficacy in pot tests were analysed using the statistical software "R." The data were tested for normal distribution and homogeneity of variance using Levene's Test $(p \leq 0.05)$ and subjected to a one-way ANOVA with "treatment" as independent variable. In the experiments that combined data from three temporally independent runs (compare Fig. 4), the effect on plant dry weight and number of plants per pot were analysed with a linear model, using "treatment" and "experiment" (=experimental run) as fixed factors.

Multiple comparisons between treatments were made using Tukey's post hoc test with p-value adjustment (significance level $p \leq 0.05$ ). Relationships between plant number and plant dry matter in pot tests as well as between inhibitions in vitro and in vivo were analysed by computing linear regressions. For relationships between in vitro inhibitions of different pathogens, Pearson's correlation coefficient (R) was computed, and the significance of the correlations tested based on two-tailed p-values.

\section{Results}

\section{Efficacy of bacterial isolates against soilborne Fusarium culmorum}

In the initial screening, 230 bacterial strains were used to inoculate maize kernels that were then sown in pots with the potting substrate inoculated with $F$. culmorum. Two weeks after sowing, the number of plants and the aboveground plant dry weight per pot were determined. The average germination rate in the healthy controls was $97.2 \%$. The majority of bacteria were tested only once, but some were included in more than one of the 22 individual experiments. The pooled results from all experiments are shown in Fig. 1a. Compared to the healthy (non-inoculated) control, the plant dry weight in inoculated pots (pathogen control) was reduced by about $90 \%$ on average. After seed treatment with about 160 strains, an increase in the plant dry weight per pot compared to the pathogen control was recorded, whereas after treatment with the remaining 70 strains, the plant dry weight was unaffected or reduced. Among the bacteria from maize roots, isolates of the gram-negative species Burkholderia cenocepacia, Pseudomonas chlororaphis ssp. aurantiaca, $P$. putida and P. corrugata (compare "Identification of bacterial isolates..." below) appeared similarly efficacious as the chemical seed treatment thiram (Fig. 1b). The best performing gram-positive bacteria from maize roots were isolates of B. megaterium, B. subtilis, B. choshinensis, B. mycoides, Paenibacillus polymyxa and Curtobacterium flaccumfaciens.

The number of plants per pot and the plant dry weight per pot were correlated $(\mathrm{R}=0.69)$; plant number was generally less affected by the infection with Fusarium than plant dry weight (Fig. 2).

\section{Identification of bacterial isolates from maize roots}

Successful identification (similarity index $\geq 0.5$ ) by gas chromatography analysis of fatty acids was achieved for 96 bacterial isolates from maize roots; two isolates were identified by rDNA sequencing and one by MALDI biotyping (Table1). Among the gram-positive species, B. megaterium constituted the largest group, followed by Brevibacillus choshinensis, other species of the genera Bacillus, Brevibacillus and Paenibacillus and four species of actinobacteria. Among the 12 gram-negative isolates identified, six were pseudomonads. Interestingly, the two strains of B. cenocepacia, one isolate of $P$. putida and the single isolates of $P$. corrugata and $P$. chlororaphis ssp. aurantiaca were the most effective strains isolated from maize roots in this study. The gram-negative bacteria also included one strain of the maize pathogen Pantoea ananatis.

\section{Activity of bacterial isolates in dual cultures}

Of the strains included in the pot tests, a subset of 107 were tested in vitro in dual cultures with $F$. culmorum, $R$. solani and G. ultimum. The in vivo and in vitro activities against $F$. culmorum (Fig. 3) were only very weakly correlated $(R=0.29)$, although the correlation was statistically significant. Of the isolates with comparatively low activity in the pot tests $(<40 \%$ dry weight relative to the healthy control), the majority had also only a low anti-Fusarium activity in vitro, but a number of isolates in this group nevertheless inhibited the pathogen in vitro by $50 \%$ or more. On the other hand, of the isolates with in vivo activity similar or higher than thiram, three (P. chlororaphis MA 342, $P$. corrugata $7437, P$. putida 7438 ) had only a low activity against $F$. culmorum in the dual cultures, whereas in the case of $P$. chlororaphis ssp. aurantiaca and strains 7353 and 7354 of B. cenocepacia, high activity in vivo was paralleled by a high activity in vitro.

The ability of the 107 isolates to inhibit the mycelial growth of $F$. culmorum in vitro was significantly correlated with ability to also inhibit $R$. solani (Tab. S 1). The correlation was especially strong for a group of about 20 isolates with high anti-Fusarium activity in vitro (not shown). Significant correlations were also obtained for the in vitro 

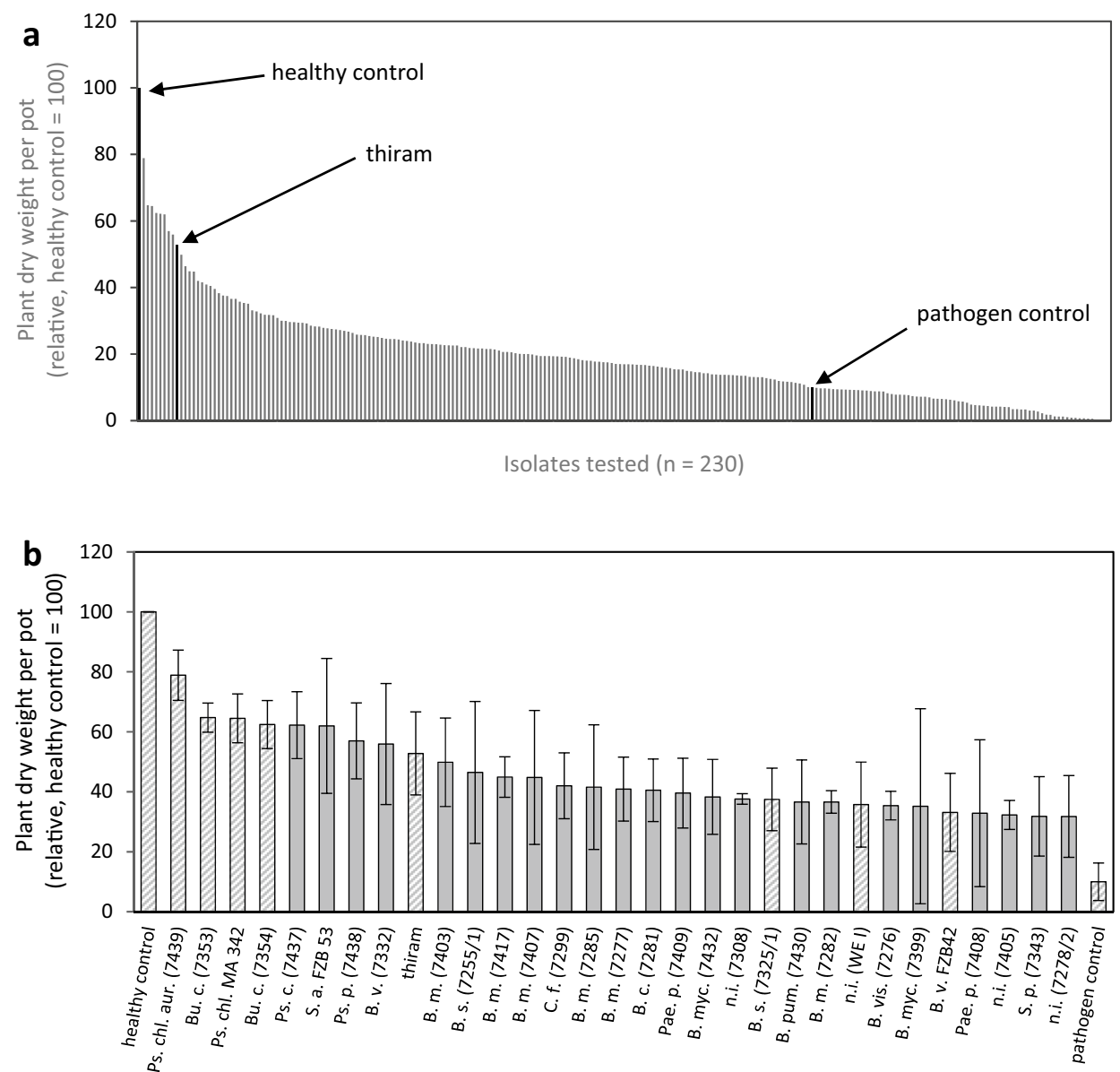

Fig. 1 Effect of seed treatment with bacteria on biomass and number of maize seedlings (seed lot 1) growing in potting substrate inoculated with Fusarium culmorum. Pooled results from 22 individual experiments. Treatments were tested in three pots with five or six seeds each A. Summary of the screening of 230 bacterial strains. B. Section from A., showing means and standard deviation of the 30 most efficacious strains. Hatched bars indicate treatments that were included in more than one of the 22 experiments (healthy control, thiram, pathogen control: $22 \mathrm{x}$; strain B. s. $(7325 / 1)$ : $7 \mathrm{x}$; strains $B$. c. (7353) and B. c. (7354): 4x; n.i. (WE I) and B. v. (FZB42): 3x; strains Ps. chl. aur. (7439) and Ps. chl. (MA 342): 2x. Abbreviations: B. c. =Bacillus choshinensis; B. v. $=B$. velezensis; B. $m .=B$. megaterium; $B$. myc. $=B$. mycoides; B. pum. $=B$. pumilus; $B . s .=B$. subtilis; B. vis. $=B$. viscosus; Bu. c. = Burkholderia cenocepacia $;$ C. $f .=$ Curtobacterium flaccumfaciens; Pae. p.=Paenibacillus polymyxa; Ps. c. $=$ Pseudomonas corrugata $;$ Ps. chl. aur. $=P$. chlororaphis aurantiaca; Ps. p. $=$ P. putida; $S$. a. =Streptomyces antimycoticus; $S$. p. $=$ Sphingomonas parapaucimobilis; $n . i .=$ not identified
Fig. 2 Scatterplot showing the relationship between plant dry weight and number of plants per pot of maize growing in potting substrate inoculated with $F$. culmorum (compare Fig. 1a)




Table 1 Species of bacteria from maize roots identified by gas chromatography of fatty acids (MIS) with similarity index $\geq 0.5$, by MALDI-TOF or by sequencing of $16 \mathrm{~s}$ rDNA, respectively, and their efficacies against soilborne $F$. culmorum

\begin{tabular}{|c|c|c|c|}
\hline Name & $\begin{array}{l}\text { Number of } \\
\text { isolates }\end{array}$ & $\begin{array}{l}\text { Average MIS } \\
\text { similarity index }\end{array}$ & $\begin{array}{l}\text { Range of activity } \\
\text { against } F \text {. culmo- } \\
\text { rum } \\
\left(\text { min. / max.) }{ }^{\text {a }}\right.\end{array}$ \\
\hline \multicolumn{4}{|l|}{ gram-positive species } \\
\hline Bacillus megaterium-GC subgroup A & 35 & 0.824 & $4.1 / 48.9$ \\
\hline Bacillus pumilus_-GC subgroup B & 5 & 0.738 & $16.5 / 36.6$ \\
\hline Bacillus viscosus & 5 & 0.809 & $21.8 / 24.9$ \\
\hline Bacillus mycoides-GC subgroup A & 5 & 0.611 & $18.9 / 38.3$ \\
\hline Bacillus cereus-GC subgroup A & 2 & 0.588 & $14.6 / 24.5$ \\
\hline Bacillus cereus-GC subgroup B & 3 & 0.605 & $15.9 / 19.3$ \\
\hline Bacillus simplex & 3 & 0.596 & $18.0 / 30.0$ \\
\hline Bacillus subtilis & 3 & $0.908^{b}$ & $22.7 / 46.4$ \\
\hline Bacillus alcalophilus & 1 & 0.566 & 27.0 \\
\hline Bacillus velezensis ${ }^{\mathrm{c}}$ & 1 & - & 55.9 \\
\hline Brevibacillus choshinensis & 10 & 0.635 & $10.7 / 40.5$ \\
\hline Brevibacillus parabrevis - GC subgroup B & 1 & 0.597 & 3.0 \\
\hline Paenibacillus polymyxa & 6 & 0.767 & $11.4 / 39.6$ \\
\hline Paenibacillus validus & 1 & 0.633 & 7.8 \\
\hline Paenibacillus pabuli & 1 & 0.551 & 18.5 \\
\hline Microbacterium laevaniformans & 2 & 0.549 & $22.9 / 23.3$ \\
\hline Microbacterium barkeri & 1 & 0.504 & 13.1 \\
\hline Curtobacterium flaccumfaciens & 1 & 0.698 & 42.0 \\
\hline $\begin{array}{l}\text { Cellulomonas fimi GC subgroup B } \\
\text { gram-negative species }\end{array}$ & 1 & 0.52 & 29.6 \\
\hline Pseudomonas chlororaphis ssp. aurantiaca ${ }^{\mathrm{d}}$ & 1 & - & 78.9 \\
\hline Pseudomonas corrugata & 1 & 0.881 & 62.2 \\
\hline Pseudomonas putida Biotype B & 3 & 0.737 & $27.7 / 57.0$ \\
\hline Pseudomonas fluorescens Biotype F & 1 & 0.591 & 29.4 \\
\hline Stenotrophomonas maltophilia & 1 & 0.512 & 9.7 \\
\hline Burkholderia cenocepacia & 2 & 0.794 & $62.4 / 64.7$ \\
\hline Pantoea ananatis & 1 & 0.629 & 21.4 \\
\hline Sphingomonas parapaucimobilis & 1 & 0.609 & 31.8 \\
\hline Chryseobacterium balustinum & 1 & 0.538 & 28.3 \\
\hline
\end{tabular}

inhibition of $F$. culmorum and $G$. ultimum as well as for in vitro inhibition of $R$. solani and G. ultimum (Tab. S 1).

\section{Efficacy of fungal isolates from maize and commercial products against soil-borne pathogens}

The fungi included in this study comprised three isolates from maize roots $(7374,7375,7376)$ and three from nodes (7414, 7415, 7416), as well as strain Clonostachys rosea IK726 and the fungal active ingredients of the commercial products Vintec (T. atroviride SC1), Soilgard (G. virens GL-21) and Prestop (C. rosea J1446). The isolates from maize differed from each other in morphology and colour of the colonies. Based on visual inspection, microscopy of the spore bearing structures and partial sequencing of the nuclear rDNA internal transcribed spacer region with primers ITS 1 and ITS4 the cultures were identified as belonging to the genus Trichoderma. In potting substrate inoculated with $F$. culmorum, the number of maize seedlings per pot was reduced by about $90 \%$ compared to the healthy control. Seed treatment with thiram and all biological agents except $G$. virens GL-21 increased the number of plants significantly (Fig. S1). The plant dry weight per pot followed a similar pattern, although in the case of two Trichoderma isolates and G. virens GL-21, 
Fig. 3 Relationship between inhibition of Fusarium culmorum in vitro and efficacy in pot tests with inoculation of the potting substrate with $F$. culmorum by 107 of the 230 bacterial strains screened (compare Fig. 1a)

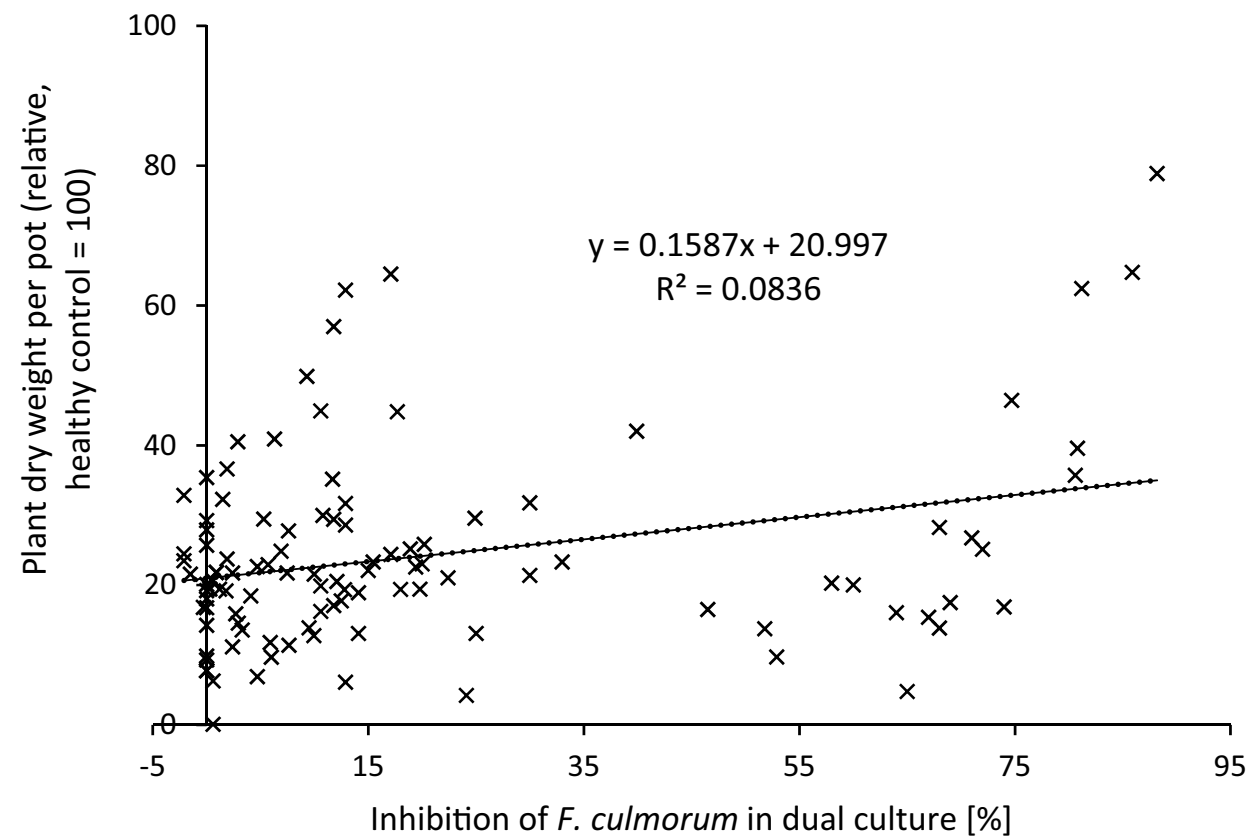

the increase was statistically not significant. The highest increase was recorded after seed treatment with the two strains of $C$. rosea, with strain $C$. rosea IK726 being as efficacious as the chemical thiram (Fig. 4a).

In potting substrate inoculated with $R$. solani, the number of plants per pot was in some treatments slightly reduced compared to the healthy control, but these reductions were statistically not significant (not shown). However, in inoculated potting substrate, the seedling height was visibly drastically reduced, resulting in a significantly lower plant dry weight per pot than in the healthy controls. Of the 11 total seed treatments tested, five failed to provide significant protection against $R$. solani, including the chemical thiram and the two strains of $C$. rosea. On the contrary, the increase in plant dry weight compared to the inoculated control was significant after seed treatment with five Trichoderma isolates and with $G$. virens GL-21 (Fig. 4b).

Only a slight and statistically not significant reduction in the number of plants was observed in potting substrate inoculated with G. ultimum (not shown), whereas the plant dry weight per pot was significantly reduced by about half (Fig. 4c). Seed treatment with thiram was ineffective, but no loss of dry weight was recorded after seed treatment with fludioxonil + metalaxyl-M. Treatment with one of the Trichoderma isolates and the two strains of $C$. rosea also resulted in a significant increase in plant dry weight per pot compared to the pathogen control.

\section{Bioassays with F. oxysporum f. sp. strigae}

The feasibility of reducing the impact of soilborne Fusarium infections by seed treatment with $F$. oxysporum f. sp. strigae was tested in a set of separate experiments. In the first, maize was sown in potting substrate artificially inoculated with the strains $5 \mathrm{a}$ or $6 \mathrm{a}$, respectively, in order to confirm their nonpathogenicity on maize. Both strains caused a low reduction in plant dry weight that was, however, statistically not significant (Fig. S2), while the number of plants per pot was unaffected (not shown). On the other hand, clear reductions in both traits were recorded in potting substrate amended with pathogenic reference strains of $F$. verticillioides, $F$. subglutinans and $F$. proliferatum. The effect of seed treatment with strains $5 \mathrm{a}$ and $6 \mathrm{a}$ on soilborne $F$. culmorum was tested in two separate experiments. With reductions in plant dry weight of more than $85 \%$ and $95 \%$, respectively, the infection pressure was high in both. Seed treatment with both strains caused increases in plant dry weight (Fig. 5) and plant number (Fig. S3, Fig. S4) compared to the pathogen control. In the first experiment, the increases in plant dry weight were significant only for strain $6 a$ at the higher concentration tested. In the second experiment, the increases in plant dry weight and plant number were significant by all four treatments with $F$. oxysporum f. sp. strigae. Nevertheless, judged by the effect on plant dry weight, the level of control by both strains of $F$. oxysporum f. sp. strigae was lower than by thiram.

\section{Bioassays to confirm activity against $F$. culmorum}

In order to confirm the activity against $F$. culmorum, a replicated trial was performed that compared the performance of strains B. subtilis 7325/1, P. chlororaphis ssp. aurantiaca 7439 and Trichoderma sp. 7376 that in the first testing were evaluated in separate experiments with different setups. 
Fig. 4 Effect of seed treatment with different fungi on biomass of maize seedlings grown in potting substrate inoculated with a. Fusarium culmorum, b. Rhizoctonia solani, and c. Globisporangium ultimum. Means and standard deviation from pooled results of three experimental runs per pathosystem, each with three replicate pots per treatment and five seeds per pot; determined 14 days after sowing. The chemical seed treatments thiram and fludioxonil + metalaxyl-M were included as references. Experiment $\mathrm{A}$ was performed with seed lot 1, experiments B and C with seed lot 2. Different letters above bars indicate statistically significant differences between the treatments (Tukey's test, $p \leq 0.05$ )
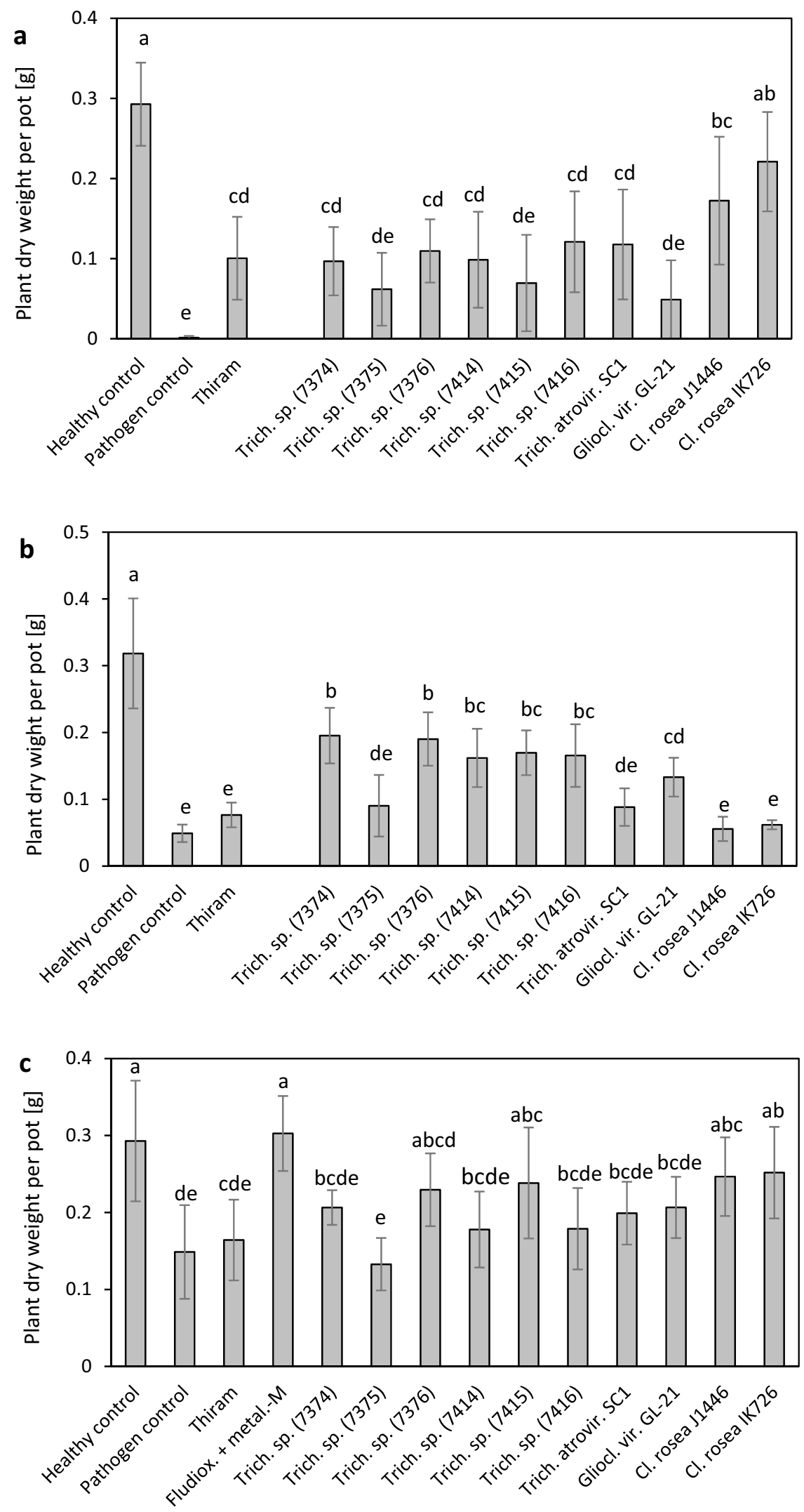


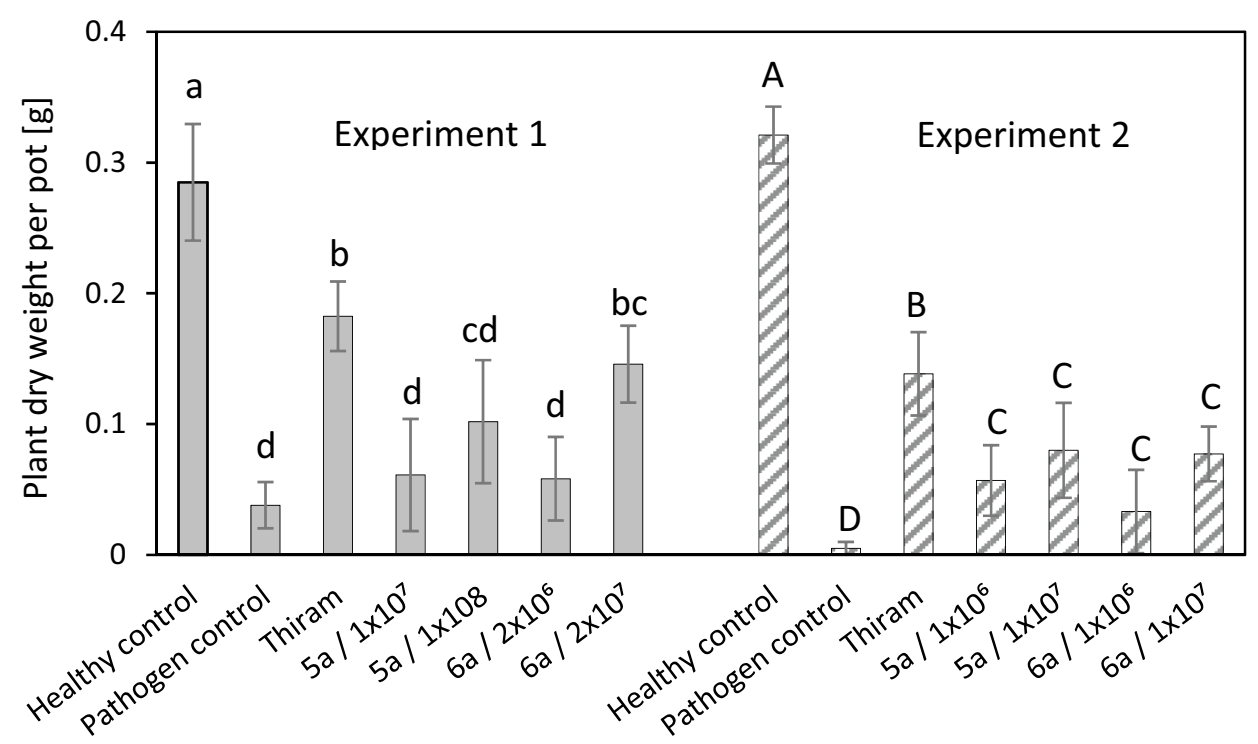

Fig. 5 Effect of seed treatment with Fusarium oxysporum f. sp. strigae strains $5 \mathrm{a}$ and $6 \mathrm{a}$ on biomass of maize seedlings (seed lot 3 ). Kernels were treated with different concentrations of conidia of both strains and sown in potting substrate inoculated with $F$. culmorum. Means and standard deviation of two separate experiments. Experiment 1 (solid bars): three replications per treatment with five pots

Sowing of the treated maize kernels in potting substrate inoculated with $F$. culmorum caused a reduction in plant dry weight per pot by about $70 \%$ compared to the healthy control. All three microbial treatments increased the plant each and five seeds per pot. Experiment 2 (hatched bars): three replications per treatment with seven pots each and five seeds per pot. Determined 14 days after sowing. Different letters above bars indicate statistically significant differences between treatments within the experiments (Tukey's test, $p \leq 0.05$ )

dry weight significantly, with the $P$. chlororaphis ssp. aurantiaca strain being the most efficacious treatment (Fig. 6). In the pathogen control, the number of plants per pot was reduced by about $35 \%$ compared to the healthy control. All

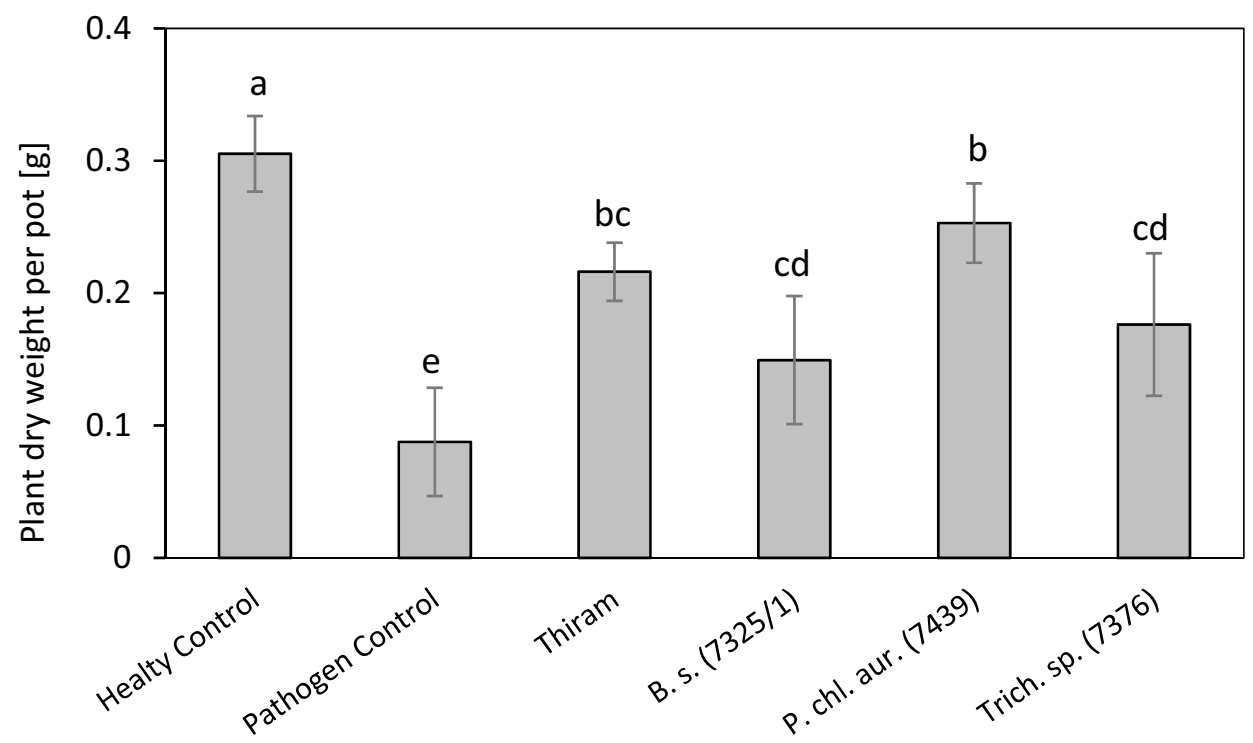

Fig. 6 Effect of seed treatment with selected antagonistic bacteria and fungi on biomass of maize seedlings (seed lot 3) grown in potting substrate inoculated with Fusarium culmorum. Means and standard deviation of one experimental run with three replications, each with four pots per treatment and five seeds per pot; determined 14 days after sowing. The chemical seed treatment thiram was included as a reference. Different letters above bars indicate statistically significant differences between the treatments (Tukey's test, $p \leq 0.05$ ). Abbreviations: B. s. =Bacillus subtilis; $P$. chl . aur $=$ Pseudomonas chlororaphis ssp. aurantiaca; Trich. $\mathrm{sp} .=$ Trichoderma $\mathrm{sp}$ 
treatments raised the number of plants per pot, some of them to the level of the healthy control (Fig. S5). In a separate trial, a significant increase in plant dry weight compared to the inoculated control was also observed for seed treatment with $S$. antimycoticus FZB53 and $F$. oxysporum f. sp. strigae $6 a$, respectively (data not shown).

\section{Discussion}

The main aim of the work presented here was to identify fungi and bacteria able to protect germinating maize seed against soilborne $F$. culmorum. In view of an expected later combined use with electron seed treatment, we used maize seed pre-treated with electrons in the screening experiments. A tiered approach with use of untreated seeds in the first round and electron-treated seeds in the second would have been preferred, but had to be rejected due to limitations of working power and time.

Due to the methodology chosen, the vast majority of the bacteria from maize roots were spore formers. It was therefore surprising that the comparatively small group of nonspore-forming bacteria isolated harboured six of the eight best performing isolates. An isolate of $P$. chlororaphis spp. aurantiaca emerged as the most efficacious bacterium from our screening experiments. A similarly high level of control was also provided by $P$. chlororaphis MA 342. Strains of the P. chlororaphis subspecies chlororaphis, aureofaciens and aurantiaca (Peix et al. 2007) have been isolated from the rhizosphere of maize (Tagele et al. 2019) and other crops and were shown to provide plant protection against an array of microbial pathogens, insects and nematodes (Anderson and Kim 2018). Among the best performing strains in our study was also one isolate each of $P$. corrugata and $P$. putida. Strains of $P$. corrugata and $P$. putida have been implicated in soil suppressiveness (Scher and Baker 1982) and were reported as biocontrol agents against different pathogens (Pandey et al. 2001; Sun et al. 2017) and able to colonize the maize rhizosphere (Ramos-González et al. 2005). We also observed a reproducibly high activity for two isolates of the risk group 2 organism Burkholderia cenocepacia. The species belongs to the Burkholderia cepacia complex that comprises species that are widespread in soil and the rhizosphere, including the rhizosphere of maize (Zhao et al. 2014), but also play a role as opportunistic pathogens in patients with cystic fibrosis (LiPuma 2005). In this regard, B. cenocepacia is generally considered the most problematic species of the B. cepacia complex (Eberl and Vandamme 2016). Its isolation from the maize rhizosphere has been reported before (Bevivino et al. 2005), and an endophytic strain with both biocontrol and plant growth-promoting characteristics has been described (Ho and Huang 2015). It is, however, difficult to predict whether a given environmental strain has the ability to cause human disease (Eberl and Vandamme 2016). Consequently, the registration as biocontrol agent may be problematic. The situation is similar for the other risk group 2 organisms isolated from maize roots: Bacillus cereus, $P$. putida, Stenotrophomonas maltophilia and Sphingomonas parapaucimobilis (BAUA 2020). The gram-negative bacteria also included one isolate of Pantoea ananatis. It did not show particularly high efficacy, but its isolation is nevertheless worth mentioning since this bacterium causes white spot disease of maize (Coutinho and Venter 2009).

The gram-positive bacteria identified in our study included the actinobacteria genera Microbacterium, Curtobacterium and Cellulomonas, and 14 species belonging to the genera Bacillus, Brevibacillus, and Paenibacillus. Among them, by far the largest group was the isolates of $B$. megaterium. Their efficacy as seed treatments against soilborne $F$. culmorum was variable whereas some isolates were almost as efficacious as the pseudomonads described above, others failed to provide any protection (data not shown). There was overall no clear relationship between species and efficacy in the pot test against $F$. culmorum, although comparability was limited due to different number of strains per species. Most of the bacteria isolated in our study from maize roots are known from the literature as rhizobacteria, many with a record as biocontrol agents on various crops including maize (e.g. Dardanelli et al. 2012, Figueroa-López et al. 2016, Shafi et al. 2017, Khaskheli et al. 2020). In addition to $P$. chlororaphis MA 342, Streptomyces antimycoticus FZB53-an agent with known anti-Fusarium activity (Koch and Löffler 2009)-and the model strain B. velezensis FZB42 (Fan et al. 2018) were included as reference. Both were among the 30 best performing strains in our screening.

As could be expected, inoculation of the potting substrate with $F$. culmorum had a negative effect not only on plant dry weight but also on plant stand. Like in preceding experiments (Koch et al. 2020), biomass was the more sensitive indicator to assess the effect of infection by $F$. culmorum. With a subset of bacteria, we compared the activity in vitro against $F$. culmorum with the activity in vivo. The results obtained were indifferent, as both characters were correlated in some of the strains but not in others. Similar relationships were reported from other pathogen-antagonist combinations (Williams and Asher 1996; Barnett et al. 2017).

Apart from the screening of bacteria for activity against F. culmorum, we also conducted bioassays for determining the activity of fungal agents against $F$. culmorum, $R$. solani and $G$. ultimum on maize. The agents tested included six isolates of Trichoderma from maize roots and nodes, strain Clonostachys rosea IK726 as well as active microbial ingredients from three commercial biocontrol products. In potting substrate inoculated with Fusarium, all agents except two Trichoderma isolates and G. virens GL-21 caused a statistically significant increase in the plant dry weight. This was 
especially surprising in the case of $T$. atroviride $\mathrm{SC} 1$, as this strain was isolated from decayed hazelnut wood (Pertot et al. 2016) and is currently approved in the EU as fungicide for the control of pathogens causing grapevine trunk diseases (European Commission 2016). On the contrary, strains of $C$. rosea are already known as competitors of the head blight pathogens of wheat, $F$. graminearum and F. culmorum (Luongo et al. 2005; Gimeno et al. 2020). Gliocladium roseum (syn. Clonostachys rosea), applied as seed treatment, suppressed seed- and soilborne pathogens of maize effectively (Vakili 1992), and C. rosea IK726 reduced the impact of $F$. subglutinans when co-applied with suspensions of the pathogen to maize seeds (Koch et al. 2020). As P. chlororaphis MA 342, strains C. rosea IK726 and J1446 (originally identified as Gliocladium catenulatum J1446) used in our study originate from a project aimed at developing microbial agents for control of seedborne pathogens on cereals (Knudsen et al. 1997). For both strains, the screening procedures included bioassays with cereal seeds naturally infested or artificially inoculated with $F$. culmorum (Knudsen et al. 1992), which may explain the high anti-Fusarium activity observed in our study. It is nevertheless worth mentioning that the isolates selected in bioassays on wheat and barley were effective also in our experiments on maize.

Despite significant reductions in losses in plant dry weight due to Globisporangium by three of the fungal biocontrol agents, G. ultimum appeared overall to be difficult to control. Full control was only provided by the chemical seed treatment Maxim XL, which can be attributed to the oomycete-specific compound metalaxyl-M contained in this product. In our experiments, seed treatment with the chemical thiram reduced the loss in plant dry weight caused by soilborne $F$. culmorum but failed to protect against $R$. solani and $G$. ultimum. The most effective agents against $R$. solani were isolates of Trichoderma and Gliocladium virens strain GL-21, the active microbial ingredient of Soilgard (Lumsden and Walter 1996). In previous experiments with peas germinating in potting substrate inoculated with $R$. solani, a comparatively high level of disease control was obtained by adding the product Soilgard to the potting substrate (Koch 1999).

Several reports in the literature show that nonpathogenic isolates of fusaria can suppress the disease symptoms caused by pathogenic species. This is well-documented in the case of the suppression of Fusarium wilt (Alabouvette et al. 2009) but appears to be valid also for Fusarium seedling diseases of cereals. For example, treatment of seeds of barley and wheat with different Fusarium spp. reduced the symptoms of seedling infections with F. culmorum (Knudsen et al. 1992), and co-inoculation of maize kernels with pathogenic $F$. subglutinans and strains of $F$. solani or $F$. oxysporum reduced the loss of plant dry weight compared to inoculation with the pathogen only (Koch et al. 2020). Apart from its role as wilt pathogen in dicot crops, Fusarium oxysporum is known as a pathogen causing disease symptoms on germinating maize seeds and seedlings. In the work presented here, we tested two strains of $F$. oxysporum f. sp. strigae. Both are known to protect maize from the parasitic weed Striga hermonthica, and one of the two is used in practical biocontrol in farmers' fields. The mode of action is related to the over-excretion of amino acids that inhibit the parasite, although the precise mechanisms of the effectiveness of strains remain to be fully clarified (Nzioki et al. 2016). In our experiments, we observed neither pathogenicity nor growth promotion of maize seedlings by the two strains of $F$. oxysporum $\mathrm{f}$. sp. strigae, but when applied as seed treatments, both reduced the impact of soilborne $F$. culmorum significantly.

To summarize, using a plant-based screening assay, we identified bacteria protecting germinating maize seed and seedlings against soilborne attack by $F$. culmorum, and fungi providing protection against soilborne F. culmorum, $R$. solani and G. ultimum. In the case of some active microbial components of commercial biocontrol products and microbial antagonists known from the literature, the previously reported activities could be confirmed. We expect that the results obtained are not only valid for seeds pre-treated with electrons but are equally applicable to untreated seeds or seeds pre-treated by other physical methods. However, further tests are necessary to prove this hypothesis. The findings are encouraging, as the level of control by some strains was comparable or close to the chemical reference seed treatment thiram. However, considering the complexity of the interactions between antagonist, pathogen, host plant and environment in the spermosphere and rhizosphere (Schroth and Becker 1990), it is obvious that greenhouse screenings can only insufficiently mirror the natural situation. For example, use of a pre-heated potting substrate, inoculation of the substrate with a single pathogen, and incubation under conditions optimal for seed germination and seedling development are far from the conditions prevailing in the field. Being aware of these limitations, we have started greenhouse and field experiments where we are testing the efficacy of formulated preparations of the microorganisms identified here as well as their use in combination with electron seed treatment.

Supplementary Information The online version contains supplementary material available at https://doi.org/10.1007/s41348-021-00498-z.

Acknowledgements Thanks are due to Dr. Annette Wensing (Julius Kühn Institute, Dossenheim) for strain determination by MALDI-TOF and to Doris Lerch and Lena van Treeck for supporting the screening work. We also wish to thank Dr. Ulf Feuerstein (Deutsche Saatveredelung AG, DSV) for supplying seeds and Dr. Peter Lüth and the Toothpick Project (https://www.toothpickproject.org/) for providing two strains of Fusarium oxysporum f. sp. strigae. 
Funding Open Access funding enabled and organized by Projekt DEAL. The research presented here was supported by funds of the Federal Ministry of Food and Agriculture (BMEL) based on a decision of the parliament of the Federal Republic of Germany via the Federal Office for Agriculture and Food (BLE).

\section{Declarations}

Conflict of interest The authors declare that they have no conflict of interest.

Open Access This article is licensed under a Creative Commons Attribution 4.0 International License, which permits use, sharing, adaptation, distribution and reproduction in any medium or format, as long as you give appropriate credit to the original author(s) and the source, provide a link to the Creative Commons licence, and indicate if changes were made. The images or other third party material in this article are included in the article's Creative Commons licence, unless indicated otherwise in a credit line to the material. If material is not included in the article's Creative Commons licence and your intended use is not permitted by statutory regulation or exceeds the permitted use, you will need to obtain permission directly from the copyright holder. To view a copy of this licence, visit http://creativecommons.org/licenses/by/4.0/.

\section{References}

Adeniji AA, Babalola OO (2018) Tackling maize fusariosis: in search of Fusarium graminearum biosuppressors. Arch Microbiol 200:1239-1255

Alabouvette C, Olivain C, Migheli Q, Steinberg C (2009) Microbiological control of soil-borne phytopathogenic fungi with special emphasis on wilt-inducing Fusarium oxysporum. New Phytol 184:529-544

Alberts JF, van Zyl WH, Gelderblom WC (2016) Biologically based methods for control of fumonisin-producing Fusarium species and reduction of the fumonisins. Front Microbiol. https://doi.org/10. 3389/fmicb.2016.00548

Anderson AJ, Kim YC (2018) Biopesticides produced by plant-probiotic Pseudomonas chlororaphis isolates. Crop Prot 105:62-69

BAUA (2020) Federal Institute for Occupational Safety and Health. Classification of biological agents in risk groups. https://www. baua.de/EN/Topics/Work-design/Biological-agents/Classification. html. Accessed 25 Aug 2020

Barnett S, Zhao S, Ballard R, Franco C (2017) Selection of microbes for control of Rhizoctonia root rot on wheat using a high throughput pathosystem. Biol Control 113:45-57

Bevivino A, Peggion V, Chiarini L, Tabacchioni S, Cantale C, Dalmastri C (2005) Effect of Fusarium verticillioides on maize-rootassociated Burkholderia cenocepacia populations. Res Microbiol 156:974-983

Buddemeyer J, Pfähler B, Petersen J, Märländer B (2004) Genetic variation in susceptibility of maize to Rhizoctonia solani (AG 2-2IIIB) - symptoms and damage under field conditions in Germany. J Plant Dis Prot 111:521-533

Chang I, Kommedhal T (1968) Biological control of seedling blight of corn by coating kernels with antagonistic microorganisms. Phytopathology 58:1395-1401

Coutinho TA, Venter SN (2009) Pantoea ananatis: an unconventional plant pathogen. Mol Plant Pathol 10:325-335

Cutrubinis M, Delincée H, Stahl M, Röder O, Schaller HJ (2005) Erste Ergebnisse zum Nachweis einer Elektronenbehandlung von Mais zur Beizung bzw. Entkeimung und Entwesung. Gesunde Pflanzen 57:129-136

Daayf F, Adam L, Fernando WGD (2003) Comparative screening of bacteria for biological control of potato late blight (strain US-8), using invitro, detached-leaves, and whole-plant testing systems. Can J Plant Pathol 25:276-284

Dardanelli MS, de Córdoba FJF, Estévez J, Contreras R, Cubo MT, Rodríguez-Carvajal MÁ, Gil-Serrano AM, López-Baena FJ, Bellogín R, Manyani H, Ollero FJ, Megías M (2012) Changes in flavonoids secreted by Phaseolus vulgaris roots in the presence of salt and the plant growth-promoting rhizobacterium Chryseobacterium balustinum. App Soil Ecol 57:31-38

Eberl L, Vandamme P (2016) Members of the genus Burkholderia: good and bad guys. F1000Research, 5, F1000 Faculty Rev-1007. https://doi.org/10.12688/f1000research.8221.1

European Commission (2016) Review report for the active substance Trichoderma atroviride SC1. SANTE/10389/2016 rev. 1

Evrendilek GA, Karatas B, Uzuner S, Tanasov I (2019) Design and effectiveness of pulsed electric fields towards seed disinfection. J Sci Food Agr 99:3475-3480

Fan B, Wang C, Song X, Ding X, Wu L, Wu H, Gao X, Borriss R (2018) Bacillus velezensis FZB42 in 2018: the gram-positive model strain for plant growth promotion and biocontrol. Front Microbiol 9:2491. https://doi.org/10.3389/fmicb.2018.02491

Figueroa-López AM, Cordero-Ramírez JD, Martínez-Álvarez JC, López-Meyer M, Lizárraga-Sánchez GJ, Félix-Gastélum R, Castro-Martínez C, Maldonado-Mendoza IE (2016) Rhizospheric bacteria of maize with potential for biocontrol of Fusarium verticillioides. Springerplus 5:330. https://doi.org/10.1186/ s40064-016-1780-x

Forsberg G, Johnsson L, Lagerholm J (2005) Effects of aerated steam treatment on cereal diseases and crop yield. J Plant Dis Prot 112:247-256

Gimeno A, Kägi A, Drakopoulos D, Bänziger I, Lehmann E, Forrer H-R, Keller B, Vogelgsang S (2020) From laboratory to the field: Biological control of Fusarium graminearum on infected maize crop residues. J Appl Microbiol 129:680-694. https://doi. org/10.1111/jam.14634

Ho YN, Huang CC (2015) Draft genome sequence of Burkholderia cenocepacia strain 869T2, a plant-beneficial endophytic bacterium. Genome Announc 3(6):e01327-e1415. https://doi.org/10. 1128/genomeA.01327-15

Jahn M, Röder O, Tigges J (2005) Electron treatment of cereal crop seeds - overview and appraisal of field trials. Mitteilungen aus der Biologischen Bundesanstalt für Land- und Forstwirtschaft Berlin-Dahlem 399:66-128

Jensen DF, Knudsen IM, Mamarabadi M, Hockenhull J, Jensen B (2007) Development of a biocontrol agent for plant disease control with special emphasis on the near commercial fungal antagonist Clonostachys rosea strain 'IK726.' Australas Plant Pathol 36:95-101

Johnsson L, Hökeberg M, Gerhardson B (1998) Performance of the Pseudomonas chlororaphis biocontrol agent MA 342 against cereal seed-borne diseases in field experiments. Eur J Plant Pathol 104:701-711

Khaskheli MA, Wu L, Chen G, Chen L, Hussain S, Song D, Liu S, Feng, G (2020) Isolation and characterization of root-associated bacterial endophytes and their biocontrol potential against major fungalphytopathogens of rice (Oryza sativa L.). Pathogens 9:172

Knudsen IMB, Hockenhull J, Jensen DF, Gerhardson B, Hökeberg M, Tahvonen R, Teperi E, Sundheim L, Henriksen B (1997) Selection of biological control agents for controlling soil and seed-borne diseases in the field. Eur J Plant Pathol 103:775-784

Knudsen IMB, Hockenhull J, Jensen DF (1992) In vivo screening of potential antagonists against F. culmorum in barley. In: Jensen 
DF, Hockenhull J, Fokkema NJ (eds) New approaches in biological control of soil-borne diseases. IOBC/WPRS Bulletin $15: 21-23$

Koch E (1999) Evaluation of commercial products for microbial control of soil-borne plant diseases. Crop Prot 18:119-125

Koch E, Löffler I (2009) Partial characterization of the antimicrobial activity of Streptomyces antimycoticus FZB53. J Phytopathol 157:235-242

Koch E, Zink P, Pfeiffer T, von Galen A, Linkies A (2020) Artificial inoculation methods for testing microorganisms as control agents of seed- and soil-borne Fusarium-seedling blight of maize. J Plant Dis Prot. https://doi.org/10.1007/s41348-020-00350-w

Köhl J, Postma J, Nicot P, Ruocco M, Blum B (2011) Stepwise screening of microorganisms for commercial use in biological control of plant-pathogenic fungi and bacteria. Biol Control 57:1-12

Lane DJ (1991) 16S/23S rRNA sequencing. In: Stackebrandt E, Goodfellow $\mathrm{M}$ (eds) nucleic acid techniques in bacterial systematic. John Wiley and Sons, New York, pp 115-175

LiPuma JJ (2005) Update on the Burkholderia cepacia complex. Curr Opin Pulm Med 11:528-533

Lumsden RD, Walter JF (1996) Development of Gliocladium virens for damping-off disease control. Can J Plant Pathol 18:463-468

Luongo L, Galli M, Corazza L, Meekes E, Haas LD, Van Der Plas CL, Köhl J (2005) Potential of fungal antagonists for biocontrol of Fusarium spp. in wheat and maize through competition in crop debris. Biocontrol Sci Techn 15:229-242

Mao W, Lumsden RD, Lewis JA, Hebbar PK (1998) Seed treatment using pre-infiltration and biocontrol agents to reduce damping-off of corn caused by species of Pythium and Fusarium. Plant Dis 82:294-299

Merriman P, Russell K (1990) Screening strategies for biological control. Biological control of soil-borne plant pathogens. In: Hornby $\mathrm{D}$ (ed) Biological control of soil-borne plant pathogens. CAB International, Wallingford, pp 427-435

Munkvold GP, O`Mara JK, (2002) Laboratory and growth chamber evaluation of fungicidal seed treatments for maize seedling blight caused by Fusarium species. Plant Dis 86:143-150

Nemţanu MR, Braşoveanu M, Karaca G, Erper I (2014) Inactivation effect of electron beam irradiation on fungal load of naturally contaminated maize seeds. J Sci Food Agr 94:2668-2673

Nzioki HS, Oyosi F, Morris CE, Kaya E, Pilgeram AL, Baker CS, Sands DC (2016) Striga biocontrol on a toothpick: a readily deployable and inexpensive method for smallholder farmers. Front Plant Sci. https://doi.org/10.3389/fpls.2016.01121

Pandey A, Palni LMS, Hebbar KP (2001) Suppression of damping-off in maize seedlings by Pseudomonas corrugata. Microbiol Res 156:191-194

Peix A, Valverde A, Rivas R, Igual JM, Ramírez-Bahena MH, Mateos PF, Santa-Regina I, Rodríguez-Barrueco C, Martínez-Molina E, Velázquez E (2007) Reclassification of Pseudomonas aurantiaca as a synonym of Pseudomonas chlororaphis and proposal of three subspecies, $P$. chlororaphis subsp. chlororaphis subsp. nov., $P$. chlororaphis subsp. aureofaciens subsp. nov., comb. nov. and $P$. chlororaphis subsp. aurantiaca subsp. nov., comb. nov. Int J Syst Evol Micr 57:1286-1290. https://doi.org/10.1099/ijs.0.64621-0

Pereira P, Nesci A, Castillo C, Etcheverry M (2011) Field studies on the relationship between Fusarium verticillioides and maize (Zea mays L.): effect of biocontrol agents on fungal infection and toxin content of grains at harvest. Int J Agron 2011. https://doi.org/10. $1155 / 2011 / 486914$

Pertot I, Prodorutti D, Colombini A, Pasini L (2016) Trichoderma atroviride SC1 prevents Phaeomoniella chlamydospora and Phaeoacremonium aleophilum infection of grapevine plants during the grafting process in nurseries. Biocontrol 61:257-267

Peters M, Gossmann M, Jahn M, Kotte M, Biermann S, Büttner C (2010) Kontamination von Maissaatgut mit Fusarium spp.
-Elektronenbehandlung als eine alternative Bekämpfungsmöglichkeit. Julius-Kühn-Archiv 428:128

Pintos Varela C, Aguín Casal O, Chavez Padin M, Ferreiroa Martinez V, Sainz Oses MJ, Scauflaire J, Munaut F, Bande Castro MJ, Mansilla Vázquez JP (2013) First report of Fusarium temperatum causing seedling blight and stalk rot on maize in Spain. Plant Dis 97:1252

Rahman MME, Ali ME, Ali MS, Rahman MM, Islam MN (2008) Hot water thermal treatment for controlling seed-borne mycoflora of maize. Int J Sustain Crop Prod 3:5-9

Ramos-González MI, Campos MJ, Ramos JL (2005) Analysis of Pseudomonas putida KT2440 gene expression in the maize rhizosphere: in vitro expression technology capture and identification of root-activated promoters. J Bacteriol 187:4033-4041

Randeniya LK, de Groot GJ (2015) Non-thermal plasma treatment of agricultural seeds for stimulation of germination, removal of surface contamination and other benefits: a review. Plasma Process Polym 12:608-623

Röder O, Jahn M, Schröder T, Stahl M, Kotte M, Beuermann S (2009) Die e-ventus Technologie-eine Innovation zur nachhaltigen Reduktion von Pflanzenschutzmitteln mit Empfehlung für BioSaatgut. E-ventus technology - an innovative treatment method for sustainable reduction in the use of pesticides with recommendation for organic seed. J Verbrauch Lebensm 4:107-117

Sauer S, Freiwald A, Maier T, Kube M, Reinhardt R, Kostrzewa M, Geider K (2008) Classification and identification of bacteria by mass spectrometry and computational analysis. PLoS ONE 3(7):e2843. https://doi.org/10.1371/journal.pone.0002843

Scher FM, Baker R (1982) Effect of Pseudomonas putida and a synthetic iron chelator on induction of soil suppressiveness to Fusarium wilt pathogens. Phytopathology 72:1567-1573

Schmidt CS, Leclerque A, Pfeiffer T, Goessling JW, Orlik M, Jamshidi B, Saar K, Sellmann J, Siepe I, Koch E (2020) Pathogenicity of Pythium species to maize. Eur J Plant Pathol 158:335-347. https:// doi.org/10.1007/s10658-020-02076-9

Schroth MN, Becker JO (1990) Concepts of ecological and physiological activities of rhizobacteria related to biological control and plant growth promotion. In: Hornby (ed) Biological control of soil-borne plant pathogens, CAB International, Wallingford, pp 389-414

Shafi J, Tian H, Ji M (2017) Bacillus species as versatile weapons for plant pathogens: a review. Biotechnol Biotechnol Equip $31: 446-459$

Sharma VK, Aulakh JS, Malik AK (2003) Thiram: degradation, applications and analytical methods. J Environ Monit 5:717-723

Sharma KK, Singh US, Sharma P, Kumar A, Sharma L (2015) Seed treatments for sustainable agriculture - A review. J Appl Nat Sci 7:521-539

Sun D, Zhuo T, Hu X, Fan X, Zou H (2017) Identification of a Pseudomonas putida as biocontrol agent for tomato bacterial wilt disease. Biolog Control 114:45-50

Tagele SB, Lee HG, Kim SW, Lee YS (2019) Phenazine and 1-undecene producing Pseudomonas chlororaphis subsp. aurantiaca strain KNU17Pc1 for growth promotion and disease suppression in korean maize cultivars. J Microbiol Biotechnol 29:66-78

Thomsen G, Birr T, Klink H, Verreet J-A (2018) Geographic distribution and disease severity of different Rhizoctonia species pathogenic towards maize in different regions in Germany and France. J Plant Dis Prot 125:461-468

Vakili NG (1992) Biological seed treatment of corn with mycopathogenic fungi. J Phytopathol 134:313-323

Whipps JM (1987) Effect of media on growth and interactions between a range of soil-borne glasshouse pathogens and antagonistic fungi. New Phytol 107:127-142 
Williams GE, Asher MJC (1996) Selection of rhizobacteria for the control of Pythium ultimum and Aphanomyces cochlioides on sugar-beet seedlings. Crop Prot 15:479-486

Zhao K, Penttinen P, Zhang X, Ao X, Liu M, Yu X, Chen Q (2014) Maize rhizosphere in Sichuan, China, hosts plant growth promoting Burkholderia cepacia with phosphate solubilizing and antifungal abilities. Microbiol Res 169:76-82
Publisher's Note Springer Nature remains neutral with regard to jurisdictional claims in published maps and institutional affiliations. 